\title{
FILM DOKUMENTER NGURI-URI BANYUMASANSEBAGAI ARSIP DIGITAL KEBUDAYAAN BANYUMAS YANG TERANCAM PUNAH
}

\author{
Ferdinanda \\ Program Studi DKV \\ Institut Teknologi Telkom Purwokerto \\ Email: ferdi@ittelkom-pwt.ac.id \\ Riri Irma Suryani \\ Program Studi DKV \\ Institut Teknologi Telkom Purwokerto \\ Email: riri@ittelkom-pwt.ac.id \\ Elianna Gerda Pertiwi \\ Program Studi DKV \\ Institut Teknologi Telkom Purwokerto \\ Email: elianna@ittelkom-pwt.ac.id
}

\begin{abstract}
ABSTRAK
Stastistik Kebudayaan Indonesia tahun 2019, memaparkan bahwa Indonesia memiliki 2.744 warisan budaya benda, 819 Warisan budaya tak benda, dan 2700 kesenian yang tersebar dalam 34 provinsi. Dari sekian banyak kebudayaan yang ada di Indonesia, dalam tulisan ini penulis akan berfokus pada kebudayaan yang terdapat di daerah Banyumas. Dinas Kepemudaan Olahraga Kebudayaan dan Pariwisata (Dinporabudpar) Banyumas meliris beberapa kesenian asli Bayumas yang terancam punah, yaitu: Gondolio, Tari Buncis, Dhalang Jemblung, Sintren, Rengkong, Cepetan, Rinding, dan Baritan. Sumber ide penciptaan dalam karya film dokumenter berjudul Nguri-uri Banyumasan ini berupa kebudayaan asli Banyumas yang terancam punah. Proses pembuatan film ini dilakukan melalui tiga tahap, yaitu pra produksi, Produksi dan Pasca Produksi. Film Dokumenter ini mendeskripsikan beberapa budaya tradisional Banyumas yang terancan punah, dengan tujuan menyediakan alternatif media informasi dalam bentuk digital. Hal ini dilakukan sebagai upaya pelestarian kebudayaan tradisional Banyumas dari kepunahan.
\end{abstract}

Kata kunci: Film Dokumenter, Arsip Digital, Kebudayaan.

\begin{abstract}
The Indonesian Cultural Statistics for 2019, explained that Indonesia has 2,744 material cultural heritages, 819 intangible cultural heritages, and 2,700 arts spread across 34 provinces. Of the many cultures that exist in Indonesia, the author, in this paper, will focus on the culture found in the Banyumas area. The Banyumas Youth Sports Culture and Tourism Service (Dinporabudpar) published several endangered Bayumas native arts, namely: Gondolio, Buncis Dance, Dhalang Jemblung, Sintren, Rengkong, Cepetan, Rinding, and Baritan. The source of the idea for the creation of this documentary film entitled Nguri-uri Banyumasan is the indigenous culture of Banyumas which is endangered. The process of making this film is carried out in three stages, namely pre-production, production and post-production. This documentary film describes several traditional Banyumas cultures that are threatened with extinction. It aims to provide an alternative media of information in digital form. This is supposed to be an effort to preserve the traditional Banyumas culture from extinction.
\end{abstract}

Keywords: Documentary Films, Digital Archives, Culture. 


\section{GEEAR Jumal Sai isulya}

\section{A. PENGANTAR}

Indonesia merupakan negara majemuk yang memiliki keberagaman suku, bahasa, kesenian tradisional hingga arsitektural yang unik pada setiap daerah merupakan kekayaan tak ternilai. Kondisi geografis berbentuk kepulauan menambah khasanah keberagaman semakin kompleks. Data statistik Kebudayaan Indonesia tahun 2019 menyebutkan Indonesia memiliki 2.744 Warisan Budaya Benda, 819 Warisan Budaya Takbenda, dan 2.700 kesenian yang tersebar dalam 34 profinsi (Kementerian Pendidikan Kebudayaan. Statistik Kebudayaan, 2019) Namun sangat disayangkan tak semua kebudayaan tersebut dikenal bahkan oleh masyarakat Indonesia sendiri. Hal tersebut dikarenakan kurangnya dokumentasi dan publikasi terhadap kebudayaan tersebut, sehingga masyarakat hanya mengenal beberapa kebudayaan saja.

Banyumas memiliki banyak kesenian tradisional yang menjadi kekayaan kebudayaan, baik itu yang sudah populer maupun kesenian tradisional yang belum terlalu dikenal oleh masyarakat luas. Dari sekian banyak kesenian tradisional Banyumas, Dinas Pemuda Olahraga Kebudayaan dan Pariwisata (Dinporabudpar) Banyumas merilis bebarapa kesenian tradisional asli Banyumas yang terancam punah. Kesenian tradisional yang hampir punah tersebut diantaranya adalah Gondolio, Tari Buncis, Dhalang Jemblung, Sintren, Rengkong, Cepetan, Rinding, dan Baritan (Radar Banyumas, 2018) Salah satu indikasi penyebab kesenian tradisional tersebut terancam punah adalah karena minimnya deskripsi berupa data dokumentasi yang tersedia, sehingga masyarakat semakin tidak mengenal kesenian tersebut.

Karya dokumenter merupakan film yang menceritakan tentang sebuah kejadian nyata yang dirangkai oleh kreatornya menggunakan ide-ide yang menarik secara keseluruhan. Artinya film dokumenter berarti menampilkan kembali fakta yang ada dalam kehidupan (Fachruddin, 2012) Fakta yang ditampilkan dalam film dokumenter merupakan salah satu bentuk pengetahuan ataupun berita yang dapat dikonsumsi oleh masyarakat. Dengan kepopuleran media audiovisual pada saat ini, film dokumenter telah dimanfaatkan sebagai salah satu media yang efektif dalam membantu proses pendidikan yaitu sebagai alternatif tontonan yang mendidik dan memberikan pengetahuan.

Film dokumenter yang mendokumentasikan kebudayaan merupakan media informasi berkonten kebudayaan yang seharusnya dapat dimanfaatkan oleh masyarakat dalam menggali pengetahuan mereka tentang kekayaan kebudayaan yang dimiliki Indonesia. Penambahan teknik sinematografi pada film dokumenter yang akan dibuat merupakan upaya yang akan dialakukan untuk menambahkan kesan dramatis pada film. Selain itu, sinematografi dinilai cukup efektif digunakan sebagai penyampai pesan kepada audience (Mahendro, 2018). Dengan demikian, pendokumentasian sebagai arsip yang berfungsi untuk melestarikan kebudayaan Banyumas yang terancam punah tersebut menjadi sangat penting untuk dilakukan. Dokumentasi kesenian tradisional melalui media audio visual berupa film dokumenter ini diharapkan dapat membantu upaya revitalisasi dan pemetaan kesenian tradisi di Kabupaten Banyumas. Selain itu juga media film dokumenter diharapkan memberikan edukasi kepada generasi muda sehingga adanya generasi penerus sebagai pendukung upaya pelestarian budaya.

\section{B. METODE PENCIPTAAN}

Proses produksi pembuatan film dokumenter terdiri dari 3 tahap, yaitu pra produksi, produksi dan pasca produksi. Dari tiga tahapan tersebut akan dijabarkan langkah-langkah penelitian sebagai berikut:

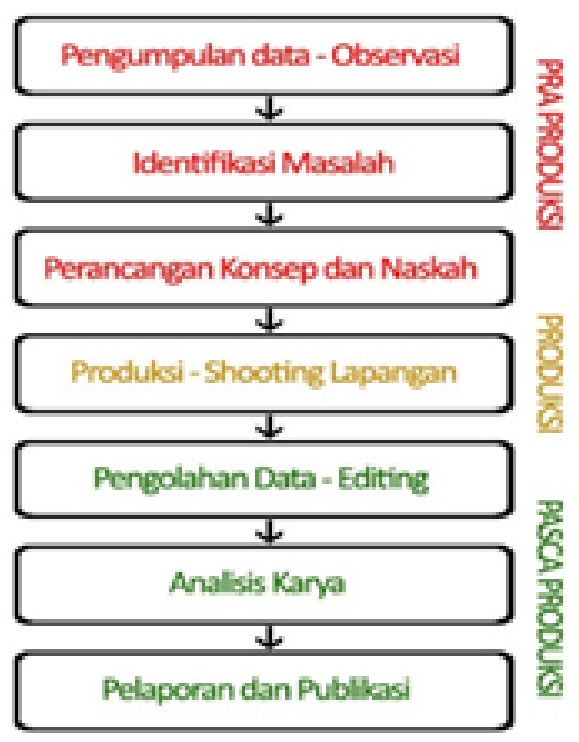

Gambar 1: Bagan Alur Penelitian

\section{Pra Produksi}

a. Pengumpulan Data

Tahap pra produksi penelitian ini adalah dengan pengumpulan data dan observasi langsung, serta menggunakan literatur buku, jurnal maupun artikel. 
b. Identifikasi Masalah

Selanjutnya data yang sudah didapatkan akan diidentifikasi dan dijadikan acuan dalam konsep penciptaan perancangan film dokumenter.

c. Konsep Perancangan

Konsep perancangan film dokumenter berupa pembuatan naskah dan pengaturan teknis. Objek yang akan divisualkan akan dipaparkan secara deskriptif, agar tujuan penelitian untuk mengenalkan seni tradisi Banyumas dapat tersampaikan ke penonton dengan baik.

\section{Produksi}

Proses produksi dilaksanakan sesuai dengan konsep dan jadwal yang ditentukan. Selain merekam wawancara dengan narasumber, pada tahap ini juga dilakukan perekaman pertunjukkan seni tradisi yang menjadi objek penelitian. Proses perekaman gambar dilakukan untuk setiap masing-masing kesenian.

\section{Pasca Produksi}

\section{a. Pengolahan Data}

Proses pengolahan data yang berupa video mentah akan dipilih, dipotong, disusun dan diolah sesuai dengan konsep dan naskah yang telah dirancang sebelumnya. Pada tahap ini juga dilakukan penambahan musik instrumen.

b. Analisis Karya

Tahap ini dilakukan analisis oleh peneliti berbentuk tulisan ilmiah. Film yang telah dihasilkan dianalisis berdasarkan teori-teori yang berkaitan dengan tatakelola budaya dan penciptaan film dokumenter.

\section{c. Pelaporan dan Publikasi}

Publikasi pada penelitian ini berupa karya ilmiah yang akan diterbitkan di jurnal Nasional bereputasi. Selain itu, film dokumenter yang dihasilkan akan didaftarkan sebagai Hak Cipta (HAKI) atas nama peneliti.

\section{PEMBAHASAN}

\section{Kesenian Tradisional Banyumas}

Indonesia merupakan salah satu negara yang kaya, tidak hanya kaya akan sumber daya alam, namun Indonesia juga kaya akan suku bangsa, ras dan kebudayaan. Keragaman inilah yang membuat Indonesia menjadi daya tarik bangsa lain dari berbagai belahan dunia untuk melihat dan bahkan mempelajarinya.

Tidak dapat dipungkiri jika saat ini, kebudayaan Indonesia mulai memudar seiring perkembangan zaman. Seiring dengan semakin berkembangnya teknologi dan era globalisasi, membuat budaya-budaya tradisional kehilangan peminatnya, terutama di kalangan generasi muda. Salah satunya adalah beberapa kesenian Tradisional di Kabupaten Banyumas, Jawa Barat yang mulai terancam keberadaanya, karena berkurangnya generasi penerus kesenian tersebut. Berikut beberapa kesenian Kabupaten Banyumas yang terancam punah dan mulai sulit ditemukan di daerah Kabupaten Banyumas:

\section{a. Gondolio}

Gondolio merupakan alat musik yang menghasilan suara dari empat bilah bambu yang tersusun menyerupai Angklung khas Pasundan. Gondolio pertama kali diciptakan oleh Ki Bangsa Setra yang pada awalnya digunakan untuk mengusir babi hutan di ladangnya, hingga akhirnya alat musik ini dijadikan sebagai salah satu musik khas di Grumbul Kalitanjung, Desa Tambaknegara, Kecamatan Rawalo, Kabupaten Banyumas.

Nama Gondolio memiliki pesan yang sangat mendalam di kalangan masyarakat setempat. Kata gondolio berasal dari kata "Gondelono ono kelean" yang artinya "Pegangan jangan sampai kehilangan". Melihat begitu dalamnya filosofi Gondolio, sangat disayangkan jika saat ini Gondolio ikut pudar di gerus zaman.

\section{b. Tari Buncis}

Kata Buncis di Banyumas tidak hanya diartikan nama sayuran, namun Buncis di Banyumas juga menjadi nama salah satu tarian tradisional yang kini terancam punah. Tari Buncis merupakan seni pertunjukan rakyat yan[g dimainkan oleh delapan orang yang menari sambil bernyanyi. Dalam sajiannya keseluruhan pemain menggunakan kostum kain yang dibuat menyerupai rumbai-rumbai dan mengenakan mahkota yang terbuat dari rangkaian bulu ayam. Sehingga hal ini membuat seni buncis banyak disebut dengan istilah "dayak-dayakan" yang berarti menyerupai kostum suku Dayak yang berasal dari Kalimantan.

\section{c. Dhalang Jemblung}

Dhalang Jemblung merupakan salah satu kesenian rakyat daerah Banyumas yang berbentuk teater tutur. Teater tutur ialah bentuk ungkapan/ kesenian dengan cara dituturkan, diceritakan dengan dinyanyikan pada mulanya hanya oleh satu orang. Dalang jemblung merupakan teater tutur yang spesifik Banyumasan, tidak diiringi oleh peralatan musik tradisional apapun melainkan diiringi oleh suara 


\section{GEEAR surmal saim iublya}

pemainnya sendiri yang bertindak sebagai musik penggiring.

Bentuk pementasan Dhalang Jemblung sangat sederhana, hanya dilakukan di dalam rumah. Para pemainnya terdiri dari empat orang, tiga orang laki-laki dan seorang wanita yang nantinya duduk melingkari sebuah meja kecil. Di mana di atas meja tersebut hanya terdapat satu peralatan, yaitu "kudhi" yaitu sebuh pisau khas Banyumas.

\section{d. Sintren}

Kesenian Sintren dikenal juga dengan nama Lais, merupakan sebuah kesenian tari tradisional yang dikenal di beberapa derah di Jawa Tengah, salah satunya di Banyumas. Kesenian ini merupakan sebuah tarian yang beraroma mistis/magis yang bersumber dari cerita cinta Sulasih dengan Sulandoro.

Sintren diperankan oleh seorang gadis perawan yang dianggap masih suci, di bantu oleh pawing dan diiringi oleh 6 orang gending. Gadis ini nanti akan dimasukkan ke dalam bentuk sebuah kurungan yang tertutup dengan kain hitam, dalam keadaan terikat tangannya. Saat kurungan diangkat, gadis yang semula telah diikat tangannya, telah berubah kostumnya dengan kostum bak seorang penari meski masih dengan tangan terikat. Dan di gadis pun siap untuk menari.

\section{e. Rengkong}

Rengkong merupakan kesenian tradisional yang telah mulai langka dan sulit untuk ditemukan di tengah-tengah masyarakat. Kesenian Rengkong sendiri tergolong sederhana, yaitu menyerupai adegan mengangkut padi setelah melakukan panen di sawah. Alat-alat yang digunakan dalam upacara ini adalah bambu, tali ijuk, minyak tanah dan dua ikat padi. Dua ikat padi ini akan diikat pada ujung-ujung bambu yang nanti diikat dengan tali ijuk dan minyak tanah digunakan untuk pengesat gesekan antara tali dan pikulan sehingga mengasilkan bunyi yang keras dari gesekan tersebut.

Suara yang dihasilkan Rengkong sangat khas, yaitu menyerupai suara katak. Para pemainnya adalah laki-laki yang biasanya menggunakan kostum celana pangsi, baju hitam, ikat kepala tanpa alas kaki. Pemainnya berjumlah lima hingga enam orang dengan durasi bermain selama satu jam.

\section{f. Cepetan}

Cepetan merupakan kesenian tari tradisional di daerah Kebumen yang dimainkan oleh 12 orang. Para pemain memakai topeng menyerupai raksana, dengan rambut panjang yang terbuat ijuk, menggunkaan pakaian hitam dan menggunakan sarung sebagai bleded di pinggang. Para pemain akan diiringi oleh musik tradisional seperti kentongan, jidur (kendang gede) dan drum. Pertunjukan Cepetan diawali dengan konvoi bersama, kemudian setelah sampai di lokasi pertunjukan, para pawing akan membakar menyan dan para pemain mulai menari. Pada puncaknya nanti beberapa dari pemain akan mengalami kesurupan, mereka yang kesurupan akan memakan berbagai sesaji yang telah disiapkan oleh para pawang, seperti daun papaya mentah, kembang, minyak wangi, kemenyan, air kelapa muda dan berbagai makanan lainnya.

Keberadaan kesenian unik ini telah ada semenjak abad XIX yang berawal dari bentuk perlawanan pada pemerintahan Hinda-Belanda, yang saat itu menguasai perkebunan luas (onderneming). Sebagai bentuk perlawanan non fisik, maka rakyat setempat membuat topeng yang terbuat dari kayu yang mudah dibentuk. Topeng-topeng ini dibuat menyeramkan untuk menakut-nakuti pemilik onderneming sehingga mereka merasa tidak betah di sana dan menyebut daerah tersebut angker. Kesenian ini sekarang sudah mulai sulit di tengah-tengah masyarakat, sesekali kita bisa menemukannya pada saat perayaan 17 Agustusan.

\section{g. Rinding}

Rinding merupakan sebuah alat tradisional asal Banyumas yang terbuat dari pelepah aren yang kering dan dirangkai dengan benang sehingga menghasilkan bunyi yang indah. Pada sejarahnya, Rinding digunakan oleh para pengembala kerbau, sapi dan kambing untuk menghibur diri dalam kejenuhan di ladang di bawah terik matahari, sembari menunggui gembalaannya. Namun kini, seiring perkembangan zaman, music Rinding sudah sangat jarang ditemui di tengah-tengah masyarakat Banyumas.

\section{h. Baritan}

Baritan merupakan upacara kesuburan dengan menggunakan kesenian sebagai media utamanya. Baritan itu sendiri terdiri dari dua jenis, yaitu Baritan yang digunakan untuk memanggil hujan dan Baritan untuk keselamatan ternak. Dalam Baritan yang digunakan untuk memanggil hujan digunakan berbagai macam kesenian seperti, lengger, buncis, atau ebeg. Sedangkan untuk keselamatan binatang ternak menggunakan lengger sebagai media upacaranya. Baritan biasanya digelar sekitar bulan September setiap tahunnya. 


\section{Film Dokumenter}

Pada awalnya, Film mengacu pada suatu benda sejenis plastik yang dilapisi dengan zat peka terhadap cahaya, yang kemudian kita kenal dengan nama celluloid. Dalam dunia Fotografi, film dikenal sebagai media yang dominan digunakan untuk menyimpan pantulan cahaya yang tertangkap oleh lensa, yang selanjutnya mulai berkembang pada penggunaan media digital sebagai media penyimpanannya. Sejalan dengan perkembangan media penyimpanan dalam bidang sinematografi, membuat pengertian film itu sendiri sudah mulai bergeser. Film yang semula dimaknai sebagai media penyimpanan, kini mulai dimaknai sebagai sebuah bentuk karya audio-visual. Film kini diartikan sebagai salah satu karya seni, yang menggunkan audio (suara) dan visual (gambar) sebagai medianya dalam proses menyampaikan pesan kepada penikmatnya.

Menurut Himawan Pratista dalam bukunya yang berjudul Memahami Film (2008), film terdiri dari tiga jenis, yaitu Film Dokumenter, Film Fiksi dan Film Eksperimental. Film Dokumenter merupakan film yang menyajikan fakta dan realita. Biasanya film dokumenter berkisah seputar orang-orang, tokoh, peristiwa dan lokasi yang nyata. Film Dokumenter tidak merekayasa atau menciptakan suatu peristiwa atau kejadian namun merekam peristiwa yang sungguh-sungguh terjadi. Film Dokumenter dapat digunakan untuk berbagai macam tujuan seperti sebagai informasi atau berita, biografi, pengetahuan, Pendidikan sosial, ekonomi, politik (propaganda) dan lain sebagainya. Selanjutnya adalah film fiksi, berbeda dengan film dokumenter, film fiksi merupakan film yang berdasarkan imajinasi si pembuatnya. Film fiksi sering menggunakan cerita rekaan di luar kejadian nyata serta memiliki konsep pengadeganan yang telah dirancang sejak awal. Terakhir adalah Film Eksperimental, yaitu film yang sangat berbeda dari 2 jenis film lainnya. Kebanyakan Film Eksperimental tidak memiliki plot, namun tetap memiliki struktur yang sangat dipengaruhi oleh insting subjektif dari sineasnya, seperti gagasan, ide, emosi serta pengalaman batin mereka. Film Eksperimental umumnya berbentuk abstrak dan tidak mudah dipahami, tidak bercerita tantang apapun dan kadang menentang kausalitas seperti yang sering dilakukan oleh para sineas surealis dan dada.

Sebagai salah satu karya audio visual yang menyajikan data dan fakta, membuat film dokumenter juga dapat dijadikan sebagai media arsip digital terhadap beberapa budaya-budaya tradisional yang mulai terancam punah. Melalui pangarsipan digital, budaya-budaya tradisional yang terancam punah dapat di awetkan dan disimpan dengan baik sebagai arsip, sehingga masih dapat dilihat dan dikembangkan suatu hari nanti oleh generasi-generasi selanjutnya.

\section{Proses Perwujudan}

Produksi Film Dokumenter terdapat tiga tahapan utama yang akan dilalui oleh sang kreatornya, yaitu proses praproduksi, proses produksi dan proses pasca produksi.

\section{a. Proses Pra Produksi}

Proses paling awal dalam sebuah produksi film Dokumenter adalah proses pra produksi. Proses pra produksi merupakan proses persiapan yang dilakukan oleh seorang kreator film sebelum masuk ke pada proses shooting atau produksi. Pada tahapan pra produksi inilah dipersiapkan segala data, fakta yang konsep yang akan diwujudkan nantinya menjadi sebuah film documenter.

Tahapan-tahapan yang dilalui oleh seorang kreator Dokumenter pada tahapan Pra produksi adalah sebagai berikut:

\section{1) Pencarian Ide dan Perumusan Konsep}

Sebuah film dokumenter berangkat dari suatu permasalahan yang terjadi di dalam masyarakat. Ide dokumenter bisa timbul atas sesuatu fenomena yang menarik, ataupun suatu kegelisahan yang dirasakan oleh sang sutradara, penulis ataupun produsernya, sehingga memutuskan untuk membuat sebuah film Dokumenter untuk menyampaikan kegelisahan ataupun pesan kepada penontonnya. Untuk itu, agar mendapatkan ide yang akan dikembangkan menjadi sebuah film Dokumenter sangat diperlukan kepekaan terhadap lingkungan sosial, budaya, politik dan alam semesta.

Setelah menentukan ide yang akan diangkat, selanjutnya adalah perumusan konsep dari subjek yang telah dipilih. Ada tiga hal mendasar yang menjadi perhatian dalam perumusan konsep ini, tiga hal tersebut adalah:

a) Apa yang akan di produksi atau dibuat.

b) Bagaimana produk tersebut akan dikemas, ini menyangkut gaya pendekatan dan bentuk.

c) Untuk apa dan untuk siapa film Dokumenter ini di produksi. Hal ini menyangkut tujuan dan target audience dari Film Dokumenter yang akan diciptakan.

Film Dokumenter yang berjudul Nguri-uri Banyumasan (Melestarikan Budaya Banyumas) ini tercipta dari kegelisan melihat beberapa kebudayaaan tradisional yang ada di lokasi domisili, yaitu Kabupaten 


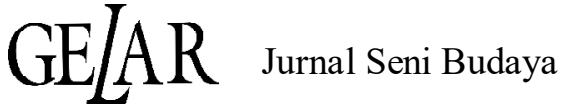

Banyumas, Jawa Tengah, yang mulai terancam punah dan semakin sulit ditemukan di tengah-tengah masyarakat. Sehingga berinisiatif memproduksi sebuah film Dokumenter yang menyajikan delapan budaya tradisional Banyumas yang terancam punah. Produksi Film Dokumenter ini diharapkan dapat menjadi arsip digital budaya-budaya tradisional ini. Sehingga membuat beberapa kebudayaan yang mulai langka ini, tidak hilang sama sekali di tengah-tengah masyarakat setempat.

\section{2) Riset Data.}

Hal mendasar yang menjadi pijakan sebuah film Dokumenter adalah data dan fakta terkait permasalahan yang akan diangkat dalam film tersebut. Sehingga, untuk mendapatkan data dan fakta yang akurat, sangat dibutuhkan riset data yang mumpuni. Yang dimaksud dengan riset adalah mengumpulkan data atau informasi melalui observasi mendalam mengenai subjek, peristiwa dan lokasi sesuai dengan tema yang akan di ketengahkan.

Untuk mendapatkan penguasaan permasalahan yang akan diangkat dengan baik, maka sangat diharakan sang kreator memiliki kedekatan dengan permasalahan yang akan diangkat. Kedetakan ini akan sangat membantu pencipta film dokumenter dalam mengetahui seluk beluk masalah yang akan diangkat. Selain itu, kedekatan dengan permasalahan yang diangkat ini juga akan membuat sang kreator lebih mengerti hal mendasar pada permasalahan yang diangkat, dan mendapatkan esensi menarik dari permasalahan tersebut.

Hasil dari riset yang dilakukan akan menjadi pedoman pijakan untuk membentuk kerangka secara global mengenai arah dan tujuan penuturan, serta subjek-subjek yang akan dijadikan tokoh dalam film dokumenter yang akan diproduksi. Tim produksi terutama Penulis Naskah dan Sutradara akan mengevaluasi hasil riset untuk mengetahui mana informasi yang penting dan kurang penting. Bagian informasi mana yang akan diperluas atau diperdalam, bagin mana sebab dan akibat peristiwa, yang digunakan untuk menunjang unsur dramatik, dan juga untuk menentukan mana bagian utama dan mana bagian pelengkap yang akan memberikan makna pada film yang akan diproduksi.

Dalam film Dokumenter ini, tim produksi tidak hanya melakukan riset pustaka dalam pencairan dan kelengkapan data-data, namun juga terjun langsung ke masyarakat guna memastikan dan melakukan observasi langsung terhadap data-data yang telah di dapat sebelumnya melalui sumber-sumber Pustaka.

\section{3) Penulisan Naskah}

Naskah dalam dokumenter sering disebut dengan treatment. Karena hanya akan berisikan garis besar pada setiap segment saja. Hal inilah yang merupakan perbedaan utama antara naskah Film Fiksi dengan naskah Film NonFiksi. Jika pada naskah film fiksi yang disebut dengan scenario, semua adegan hingga dialog akan dituliskan secara rinci, karena semua itu atas rekayasa si pembuat filmnya. Berbeda dengan naskah nonfiksi, dimana kita hanya bisa menuliskan poin-poin dan garis besarnya saja, secara detailnya akan kita dapatkan saat kita produksi di lapangan.

Naskah yang akan di produksi dapat dilihat pada gambar berikut

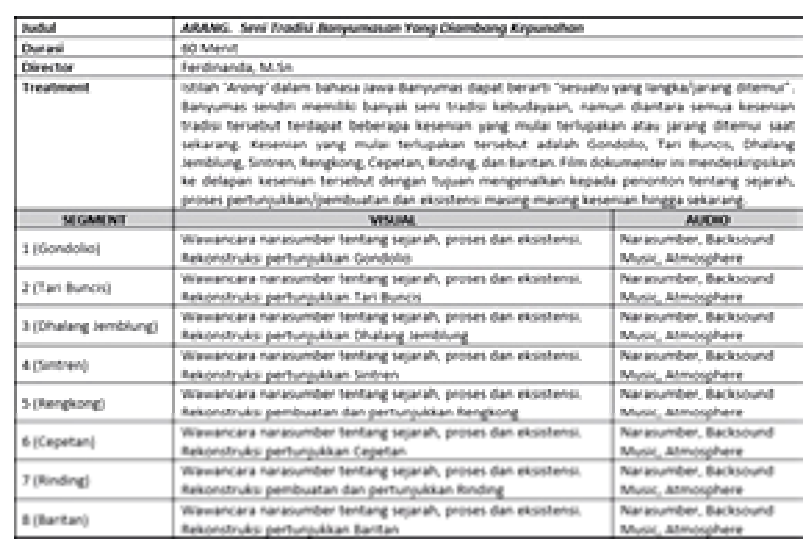

Tabel 1. Naskah Film Dokumenter

\section{b. Proses Produksi}

Proses produksi merupakan proses pengambilan gambar yang dilakukan oleh penulis dan tim kerabat kerja yang terlibat. Proses produksi dalam menciptakan film adalah berupa proses perekaman gambar atau yang sering disebut dengan shooting. Proses produksi film dokumenter yang berjudul Nguriuri Banyumasan ini dilakukan beberapa minggu. Hal ini disebabkan oleh sulitnya menemukan ritual delapan budaya yang terancam punah di Kabupaten Banyumas dan orang-orang yang mengerti akan seluk beluk serta filosofi dari upacara tersebut.

Dalam Film Dokumenter berjudul Nguri-uri Banyumasan ini mengungkap delapan budaya yang terdapat di Kabupaten Banyumas yang saat ini terancam punah dan mulai sulit ditemukan di tengahtengah masyarakat. Film Dokumenter ini juga mengutarakan alasan-alasan mengapa kebudayaankebudayaan tradisional ini mulai hilang di dalam masyarakat, salah satu pemicunya adalah kurangnya minat generasi muda saat ini untuk mempelajari dan 
melestarikan budaya tradisional, di tengah-tengah zaman teknologi digital seperti saat sekarang ini.

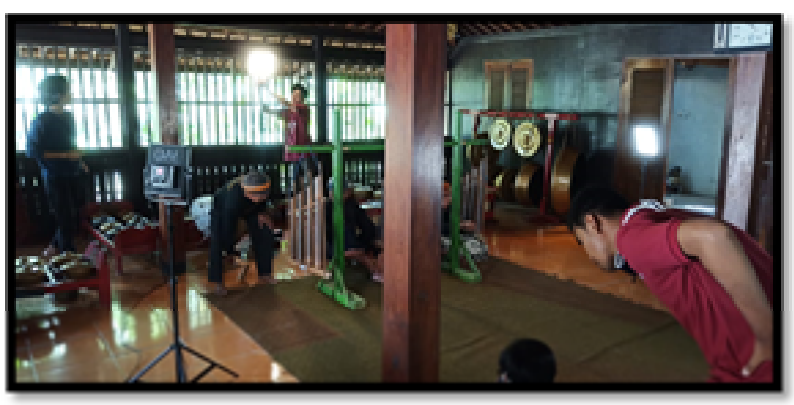

Gambar 2. Proses Produksi

\section{c. Proses Pasca Produksi}

Editing atau pascaproduksi, adalah proses ketika bagian-bagian film atau video; visual, tata suara, kata, musik, dan teks, dijalin bersama melalui penuturan cerita (storytelling) dalam proses peralihan gambar menjadi satu rangkaian gambar untuk menciptakan makna (Sam Gregory dan Gillian Caldwell, 2008:198). Dalam film Dokumenter ini, pengeditan atau penyunting video merupakan langkah yang sangat penting. Hal ini disebabkan karena dalam pengeditan inilah video yang semula masih bersifat original dan acak, di edit menjadi sebuah tayangan yang menarik, memiliki alur dan menjadi satu kesatuan utuh sebagai sebuah film dokumenter.

Di proses editing, editor akan melalui dua proses yaitu editing offline dan editing online. Editing Offline merupakan proses penyuntingan gambar hasil shooting sesuai dengan konsep dan naskah yang telah disiapkan saat proses pra produksi. Setelah semuanya tersusun sesuai dengan naskah, maka selanjutnya editor akan melakukan proses editing online, yaitu proses pengisian musik, narasi dan efek-efek yang diperlukan untuk menciptakan estetika atau keindahan dalam film Dokumenter ini.

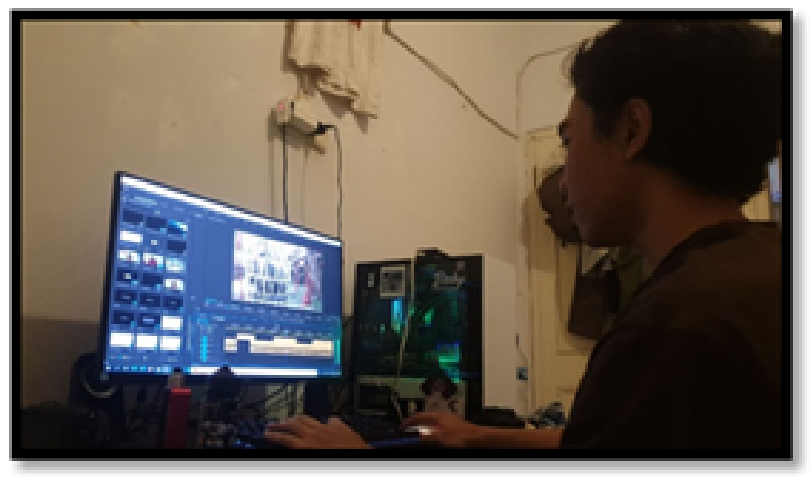

Gambar . Proses Editing Film

\section{KESIMPULAN}

Pesatnya era teknologi dan digitalisasi pada zaman serba modern ini tak dapat dipungkiri dapat memanjakan masyarakat dengan berbagai kemudahan-kemudahan yang didapat. Hal ini tak pelak membuat masyarkat terutama generasi muda larut di dalamnya, dan mulai melupakan untuk melestarikan budaya-budaya tradisional yang dimiliki. Hal ini tentu tidak sepenuhnya salah, karena bagaimanapun teknologi juga telah memberikan dampak positif dan berbagai kemudahan dalam hidup bermasyarakat. Salah satu manfaat dari masa digitalisasi ini adalah, masyarakat juga bisa melakukan pelestarian budaya tradisional yang beberapa diantaranya mulai terancam punah, melalui sebuah karya audio visual yang dapat dijadikan sebagai arsip digital.

Pengarsipan aset-aset budaya secara digital dinilai sangat penting karena dalam memelihara, melestarikan dan mengawetkan warisan bangsa secara turun-temurun.

\section{KEPUSTAKAAN}

Ayawaila, Gerzon. 2008. Dokumenter dari Ide sampai Penciptaan. Jakarta. Fakultas Film dan Televisi IKJ.

Fachruddin, Andi. 2012. Dasar-Dasar Produksi Televisi. Jakarta: Kencana.

Gregory, Sam \& Gilian Caldwell. 2008. Video For Change. Yogyakarta. INSIST Press.

Mahendro, Adib Joko. 2018. Teknik Sinematografi Dalam Menggambarkan Pesan Tawakal Pada Film Dokumenter "Dolanan Kehidupan". Skripsi Universitas Islam Sunan Kalijaga Yogyakarta.

Panjaitan, Ruqiah Ganda Putri dkk. 2019. Film Dokumenter Sebagai Media Pembelajaran Submetri Zat Aditif. Jurnal Pendidikan Biologi (JPBIO) Vol. 4, No. 2.

Prananda, Moh. Namiraz dkk. 2018. Efektivitas Sumber Pembelajaran Sejarah. Jurnal Pendidikan Sejarah, Vol 7 No 2.

Pratista, Himawan. 2008. Memahami Film. Yogyakarta. Homerian Pustaka. 


\section{GELAR Jumal sari butsya}

Ramadhan, Muhammad Nuzula. 2017. Teknik Sinematografi Dalam Menyampaikan Pesan Nasionalisme Pada Program Tayangan Indoensia Bagus Edisi Maumere di Net TV. Skripsi Universitas Islam Sunan Kalijaga Yogyakarta.

Wahyuningsih, Novinda. 2016. Efektivitas Penggunaan Media Film Dokumenter Terhadap Kemampuan Menulis Puisi Siswa Kelas VII SMP Pangudi Luhur 1 Kalibawang Kulon Progo. Skripsi Universitas Sanata Dharma Yogyakarta

\section{SUMBER INTERNET}

Artikel Radar Banyumas, 2018. Delapan Kesenian Tradisi Banyumas Terancam Punah: https:/ /radarbanyumas.co.id/delapan-keseniantradisi-banyumas-terancam-punah/

Kementerian Pendidikan Kebudayaan. Statistik Kebudayaan 2019. Jakarta: Pusat Data dan Statistik Pendidikan dan Kebudayaan Kementerian Pendidikan dan Kebudayaan 